\title{
HOW DO ACCOUNTING STUDENTS PERCEIVE EMPLOYER - EMPLOEE RELATION? QUALITATIVE RESEARCH WITH USAGE OF ZOOMORPHIC METAPHOR
}

\begin{abstract}
Employer-employee relation is a subject of many groups, including students who are about to make their career choice and enter the labor market. The goal of the paper is to identify and explore the accounting students perception of employee's and employer's roles and the relation between them. The following research questions are addressed: 1) How do accounting students perceive the role of employer? 2) How do accounting students perceive the role of employee? 3) How do accounting students perceive the relation between employer and employee? The considerations presented in the paper are made in interpretative-symbolic management paradigm. The inductive approach is taken. Qualitative research is applied. The Forced Metaphor-Elicitation Technique is used. The results are based on metaphors and narration analysis. The research shows that although three aspects of description: attributional, behavioral and relational can be distinguished, all of them constitute the meaning given by the students to the employer-employee relation. The employer is characterized mostly by his features, mainly dignity, force and self-assurance. Employee is described predominantly by his contribution to his work and his attitude towards employer, esp. respect and fear and, sometimes, also attempts of tricking him. The relation between employer and employee is perceived then mostly in the power-subordinance context. It is seen as unsymmetrical, esp. in the sphere of mutual influence. The impact of employer on employees is perceived to be strong in many dimensions. The influence of one single employee on employer and his business is reckoned to be rather insignificant.
\end{abstract}

Keywords: employer's role, employee's role, employer-employee relation, accounting students, perception, zoomorphic metaphor, projection techniques, forced-Metaphor Elicitation technique.

\section{INTRODUCTION}

Employer-employee relation is a subject of interests of lawyers, human resources specialists, labor unit members, politicians, employees and employers themselves and, last but not least, students who are about to make their career choice and enter the labor market. The professional preferences are influenced by many factors, anyway the perception of relation between employer and employee is undoubtfully one of them. The paper investigates

\footnotetext{
${ }^{1}$ Marta Nowak DSc, PhD, Associate Prof., Wrocław University of Economics, Department of Accounting Theory and Financial Analysis, e-mail: marta.nowak@ue.wroc.pl. Dr hab. Marta Nowak, prof. UE, Uniwersytet Ekonomiczny we Wrocławiu, Katedra Teorii Rachunkowości i Analizy Finansowej, e-mail: marta.nowak@ue.wroc.pl.
} 
the perception of this relation of specific group of new labor market players - accounting students. Therefore, the results can be of interest for scholars representing various disciplines and sub-disciplines, such as human resources management, accounting, labor sociology, social psychology.

The goal of the paper is to identify and explore the accounting students perception of employee and employer roles and the relation between them. The following research questions are addressed:

Q1) How do accounting students perceive the role of employer?

Q2) How do accounting students perceive the role of employee?

Q3) How do accounting students perceive the relation between employer and employee?

The considerations presented in the paper are made in interpretative-symbolic management paradigm. The inductive approach is undertaken and qualitative research is used.

\section{METHODOLOGY}

The study presented in the paper has the character of the qualitative research, which "is concerned with developing explanations of social phenomena [...], it aims to help us to understand the social world in which we live and why things are the way they are [...] it ,,is concerned with the social aspects of our world ${ }^{2}$. Inductive method is applied. Consequently, firstly the gathering and elaboration of research material was done. It was followed by interpretation and summed up by the research conclusions The Forced Metaphor-Elicitation Technique introduced by A.G. Woodside ${ }^{3}$ was applied. The respondents were asked about the animals they associate with employer and employee. The explanation of chosen metaphors was also obligatory. More than one metaphor for each role could be proposed. The answers were anonymous and delivered in the written form. The interpretation of so-acquired material was focused mainly on metaphor choice and, predominantly, on explanation discourse (narration).

Metaphors appear in everyday and science frequently. „Metaphorical concepts of all types arise naturally from physical and cultural experience. [...] Most [of them], however, are clearly dependent on culturally relative activities and experiences. $[\ldots]^{4}$. It can be proved by the analyses made in different cultures, by research by Z. Jing-Schmidt and Peng $X .^{5}$ on metaphor choice in China's anti-corruption discourse. Moreover, it ,is is unlikely that metaphor use is inevitable or manifests in the same fashion across individuals and situations. [...] Metaphor ,use functions to support subjective comprehension by reducing abstractness" 6 . Metaphors were used and were subject to many researches in different sciences. Investigation of metaphor processing in schizophrenia patients can serve as

2 B. Hancock, K. Windridge, E. Ockleford, An Introduction to Qualitative Research, The NIHR RDS EM / YH, 2009, p. 7.

3 A.G. Woodside Using the Forced Metaphor-Elicitation Technique (FMET) to Meet Animal Companions within Self, "Journal of Business Research" 2008, No. 61.

4 G. Lakoff, M. Johnson, The Metaphorical Structure of the Human Conceptual System, „Cognitive Science" 1980, No. 4, p. 201.

5 Z. Jing-Schmidt, X. Peng, Winds and tigers: metaphor choice in China's anti-corruption discourse, "Lingua Sinica" 2017, 3:2, p. 1-26.

${ }^{6}$ M. Baldwin, M.J. Landau, T.J. Swanson, Metaphors can give life meaning, Self and Identity, August 2017, p. 3. 
example ${ }^{7}$. Narration analysis is also important as for "almost all qualitative methods of research, language is at one and the same time subject and medium. It is used above all as material referring to content outside language: patterns of relationships, latent structures of meaning ${ }^{8}$. Therefore full results of study can be obtained by analyzing metaphors themselves enriched by analyzing content of the language.

The data was collected in spring 2017 at Wroclaw University of Economics. The purposive sampling was applied. The respondents recruited from a last, third year of regular bachelor students majoring in accounting and auditing. The research group consisted of 37 persons. Therefore the sample is not huge but appropriate for qualitative studies. Among them, the $62 \%$ were female and $38 \%$ male. Such a gender structure is caused by the general high level of feminization of accounting studies in Poland. Most of respondents, namely $62 \%$ was 21 years old, $30 \%$ of them were 22 years old, the least numerous. $8 \%$, were 23 -yeats old students. Such age structure is a consequence of the fact that in Poland usually young people start their regular bachelor studies just after finishing the comprehensive school and passing their maturity examination. In the opposite, the weekend (extramural) studies are usually undertaken by people who work on full-time jobs, therefore their age tends to be more differentiated.

\section{RESEARCH RESULTS}

The collected research material is presented in tables 1 and 2. Neither shortages nor changes were made and the only interference of the author of this paper is translation from Polish into English. The plural or singular character of nouns as well as circumscriptions remained unchanged. The purpose of such approach is that also the used language can be subject to analysis and interpretation, especially when it comes to ascribing positive or negative connotations to the object.

Analyzing the justifications of usage of given metaphors of employer (presented in table 1) it was identified that most of them contain one or more of following dimensions:

- behavioral dimension - related to behavior of employer and/or chosen animal;

- attributive dimension - linked with certain character features;

- relational dimension - concerning relations which are entered by given person ion professional situations.

The behavioral-style narration is reflected in statements such as "[...] he works as horse on land $[\ldots]$ " or "[...] watches over everything that happens in company [...]". The examples of attributive approach are: ,[...] huge and [...] terrifying [...]" or "[...] individualist [...]". The relational dimension (usually containing also two previous approaches) can be noticed in sentences such as: "[...] cats [...] subdue all householders, they cannot be commanded as they do what they want anyway [...]", "[...] king of his jungle; can chase other animals [...]". It should be stressed, however, that in this dimension, the employer-employee interdependence is not the only one taken into account. Also description of relations

7 A. Pawełczyk, E. Łojek, T. Pawełczyk, Metaphor processing in schizophrenia patoens: a study of comprehension and explanation of metaphors, "Psychology of Language and Communication" 2017, Vol. 21, No. 1, p. 287-306.

${ }^{8}$ R. Schmitt, Systematic Metaphor Analysis as a Method of Qualitative Research, "The Qualitative Report" 2005, Vol. 10, No. 2 June, p. 358. 
with company's surrounding and competitors is used $(,[\ldots]$ must be clever and outpace their competition [...]").

Table 1. Zoomorphic metaphors of employer

\begin{tabular}{|c|c|}
\hline \begin{tabular}{|l|} 
Zoomorphic \\
metaphor/number of \\
respondents/female \\
respondents/male \\
respondents
\end{tabular} & Explanation 9 \\
\hline Lion $17 / 15 \mathrm{f} / 2 \mathrm{~m}$ & $\begin{array}{l}\text { - is self-confident, charismatic, revealing leadership features, self-righteous, } \\
\text { choleric, narcissus } \\
\text { - is majestic and commanding respect similarly to employer in a company } \\
\text { - is a king of his jungle; can chase other animals; takes care of his pack and } \\
\text { his territory } \\
\text { - king of animals, rules over others; makes all decisions } \\
\text { - employer should be a "king" in his kingdom - company; should be alert and } \\
\text { attentive during both selection and team management, should by not be } \\
\text { astonished and react rapidly } \\
\text { - because he is strongest; he has to be obeyed, he is most important in the } \\
\text { pack, he is responsible for his employees } \\
\text { - he is serious and everybody respects him because of being afraid of being } \\
\text { attacked } \\
\text { - because it associates for me with individualism and power; company is his } \\
\text { territory } \\
\text { - because it associates for me with power; he manages the company } \\
\text { - exhibits domination skills, he is acknowledged as king, he is majestic, he } \\
\text { commands respect } \\
\text { - he should be courageous, have the authority and predominate the pack, in } \\
\text { this case employees, he has to be courageous and make such decisions which } \\
\text { let the organization survive } \\
\text { - dangerous, pack leader, commands respect - such should be a good em- } \\
\text { ployer } \\
\text { - it should be a brave person, leading, firm; he should at the same time care } \\
\text { about employees - pack; lion causes fear among other animals, but also } \\
\text { commands admiration } \\
\text { - strong, self-confident, pack leader; able to be dangerous } \\
\text { - commander of pack, ruling, strong } \\
\text { - lion, because employer manages all the company, watches over everything } \\
\text { that happens in company, gives orders to his employees } \\
\text { - wild lion from African savannas - employer is determined to achieve his } \\
\text { goal, he is winning his position on the market in a predatory way, sometimes } \\
\text { not paying attention to other entrepreneurs (other animals) }\end{array}$ \\
\hline
\end{tabular}

9 When the explanation is formulated beginning with ,it" - that means that respondent refers to animal; if it starts by „he”- the respondent refers his explanation to employer or employee. 
Table 1 (cont.). Zoomorphic metaphors of employer

\begin{tabular}{|c|c|}
\hline $\begin{array}{l}\text { Zoomorphic } \\
\text { metaphor/number of } \\
\text { respondents/female } \\
\text { respondents/male } \\
\text { respondents }\end{array}$ & Explanation $^{10}$ \\
\hline Snake $2 / 1 \mathrm{f} / 1 \mathrm{~m}$ & $\begin{array}{l}\text { - frightful and dangerous reptile; animal, which better should be avoided and } \\
\text { kept at a huge distance from } \\
\text { - cunning, loner, it never can be known when it attacks - comes to inspect } \\
\text { and criticize }\end{array}$ \\
\hline $\begin{array}{l}\text { Whale or elephant } \\
1 / 1 \mathrm{f}\end{array}$ & $\begin{array}{l}\text { - is huge; employs many workers (as I work in a big corporation); it associates } \\
\text { for me with sth big because it plays a huge role in the life of a person and } \\
\text { local society }\end{array}$ \\
\hline Whale $1 / 1 \mathrm{f}$ & $\begin{array}{l}\text { - is huge and can be terrifying but in the matter of fact it is gentle it does not } \\
\text { attack without reason, even though it can defend its pack }\end{array}$ \\
\hline Bull 1/1f & $\begin{array}{l}\text { - it can blow off and sometimes incorrectly thinks that is only one and the } \\
\text { best; is domineering and lacks of tact }\end{array}$ \\
\hline Tiger $1 / 1 \mathrm{~m}$ & $\begin{array}{l}\text { - he should be responsible for company, have ability to win with competition, } \\
\text { be firm }\end{array}$ \\
\hline Cat $3 / 3 \mathrm{f}$ & $\begin{array}{l}\text { - cats walk thorough their own parts, subdue all householders, they cannot be } \\
\text { commanded as they do what they want anyway } \\
\text { - individualist able to manage everyone around } \\
\text { - master of everything and of everybody }\end{array}$ \\
\hline Eagle 1/f1 & $\begin{array}{l}\text { - he is the most important person, he should be distinguished by majesty; } \\
\text { eagle possesses the wings and also employers should take the direction of } \\
\text { action, flying course; eagles are characterized by sharp eyesight, also the } \\
\text { employer must catch the glimpse of changes on market and chances of } \\
\text { development }\end{array}$ \\
\hline $\begin{array}{l}\text { Queen of ants in } \\
\text { ant-hill } 1 / \mathrm{f} 1\end{array}$ & $\begin{array}{l}\text { - queen of ants is a most important ant and all other ants work for her exist- } \\
\text { ence by building the ant-hill }\end{array}$ \\
\hline $\begin{array}{l}\text { Queen of bees in } \\
\text { beehive } 1 / \mathrm{f} 1\end{array}$ & - similarly to the queen of ants case \\
\hline Owl 1/1m & $\begin{array}{l}\text { - the employer takes a huge responsibility both for the entire company and for } \\
\text { the employing the proper worker for the given position; he should be able } \\
\text { to notice the potential and skills of his workers in order to use their work } \\
\text { maximally }\end{array}$ \\
\hline Cheetah 1/f1 & - he drives the crew to work, commands respect and sometimes also fear \\
\hline Dog 1/f1 & $\begin{array}{l}\text { - it associates with a person who watches over the order, place, it is often } \\
\text { concrete sometimes also firm person }\end{array}$ \\
\hline $\begin{array}{l}\text { Hippopotamus } \\
1 / \mathrm{m} 1\end{array}$ & $\begin{array}{l}\text { - is important, commands respect, is rather ponderous, not moving, observing } \\
\text { the work of his subordinates }\end{array}$ \\
\hline
\end{tabular}

${ }^{10}$ When the explanation is formulated beginning with ,it" - that means that respondent refers to animal; if it starts by „he” - the respondent refers his explanation to employer or employee. 
Table 1 (cont.). Zoomorphic metaphors of employer

\begin{tabular}{|c|c|}
\hline \begin{tabular}{|} 
Zoomorphic \\
metaphor/number of \\
respondents/female \\
respondents/male \\
respondents
\end{tabular} & Explanation $^{11}$ \\
\hline Shark $2 / \mathrm{f} 2$ & $\begin{array}{l}\text { - because everybody fears him; commands respect; is able to fight for his own } \\
\text { goal } \\
\text { - constantly aims for achieving the possible best results often at cost of his } \\
\text { workers who feel respect for him and often fear to resist }\end{array}$ \\
\hline Cock 1/f1 & $\begin{array}{l}\text { - [part of the text is unreadable]: defends its group [unreadable]; he decides } \\
\text { who will be the part of this group, choses, by the proper selection, the ,hens” } \\
\text { which will be most precious for the group; responsible for group }\end{array}$ \\
\hline Cow $1 / f 1$ & - 'boos' sometimes without a need \\
\hline Donkey1/f1 & - sometimes is stubborn as donkey, even thought when he is not right \\
\hline Sloth 1/f1 & - does nothing; picks holes in hard-working man's job \\
\hline Wolf $1 / f 1$ & $\begin{array}{l}\text { - rules in his pack, demands a lot from others; everybody fear him; he is a } \\
\text { VIP in pack }\end{array}$ \\
\hline Horse 1/f1 & $\begin{array}{l}\text { - because he works as horse on land, hard and not necessarily because he } \\
\text { wants to do it }\end{array}$ \\
\hline Fox 1/f1 & $\begin{array}{l}\text { - sometimes the employees are cunning, they care only about their own prof- } \\
\text { its, they must be clever and outpace their competition }\end{array}$ \\
\hline Peacock 1/f1 & $\begin{array}{l}\text { - often proud of his achievements and his possessions - both financial and } \\
\text { professional }\end{array}$ \\
\hline
\end{tabular}

Source: own elaboration.

Most justifications connected with relations concern directly superior-subordinate (power-dependence) relation. In most of the cases, the employer is perceived as commanding estimation, respect or even fear and terror. Two kinds of narration are involved then. One type possess positive connotation (esteem) and second type negative connotation (fear). Analyzed narration links this fear or respect to some attributes of employer such as majesty or power to impose various repressions (including threat of firing worker). Moreover, the courage is attributed to employer. Also he is perceived to be clever and cunning in his contacts with his employees as well as with his competitors. The narration analysis shows that positive and negative attributes of employer exist. He is responsible for workplace and employees and exhibits many competences (such as team management and proper selection of people). Nevertheless, he is also perceived to be excessively proud and even narcissus.

It should be emphasized that analysis of metaphors and narration depicts relatively coherent view of the employer's figure. Even though there are positive and negative connotations, the opinions usually mean just two sides of the same coin (eg. commanding respect versus commanding fear or self-confidence versus narcissism). Also, the very distinctive

11 When the explanation is formulated beginning with ,it" - that means that respondent refers to animal; if it starts by „he" - the respondent refers his explanation to employer or employee. 
position of employer was identified. He is perceived as master of everyone and everything, playing significant role in the life of his employees and controlling his territory. Additionally, it should be stressed, that the selection of metaphors itself is connected to wide extent to the typical symbolic meaning of animals, eg. symbols of power (lion), pride (lion, peacock), cunningness (snake) ${ }^{12}$.

Table 2. Zoomorphic metaphors of employee

\begin{tabular}{|c|c|}
\hline $\begin{array}{c}\text { Zoomorphic } \\
\text { metaphor/number } \\
\text { of respondents/female } \\
\text { respondents/male } \\
\text { respondents }\end{array}$ & Explanation of metaphor \\
\hline Common sloth $1 / \mathrm{f} 1$ & $\begin{array}{l}\text { - does everything in slowed-down motion, does not feel the pressure } \\
\text { according to rule ,no matter if you stand or if you lay”"13 }\end{array}$ \\
\hline Sloth $2 / \mathrm{f} 2$ & $\begin{array}{l}\text { - sometimes, when the employer is not present, employee takes advantage } \\
\text { of such situation and does nothing } \\
\text { - slow and lazy, has time for everything }\end{array}$ \\
\hline $\operatorname{Dog} 5 / 4 \mathrm{f} / 1 \mathrm{~m}$ & $\begin{array}{l}\text { - has to perform the commands, must be faithful to his job and keep good } \\
\text { relations with team, similarly to dog loyal to its owner } \\
\text { - must be obedient to his employer; should be loyal to its workplace and } \\
\text { its employer; if something happens, he must be available in each mo- } \\
\text { ment } \\
\text { - with no doubt, each employer wants to have a devoted employee; such } \\
\text { worker surely will do his job in a proper way } \\
\text { - associates for me in the manner that he is loyal and subdued to his } \\
\text { employer } \\
\text { - employee fulfils the commands which are given by his employer, is } \\
\text { attached to the company and is loyal unless he gets a better offer }\end{array}$ \\
\hline Trained doggy $1 / 1 \mathrm{~m}$ & - he listens to the employer but in the crisis situation he can bite or bark \\
\hline Rat $1 / 1 \mathrm{~m}$ & $\begin{array}{l}\text { - he competes for cheese pieces with other rats as employees in corpora- } \\
\text { tion }\end{array}$ \\
\hline Ox $2 / \mathrm{f} 1 / \mathrm{m} 1$ & $\begin{array}{l}\text { - he performs hard work; he can be devoured by lion-employer if he does } \\
\text { not escape fast enough (if he does not complete his tasks) } \\
\text { - because it has to work hard in order to survive it has to keep within his } \\
\text { pack }\end{array}$ \\
\hline Ants, small fishes $1 / \mathrm{f} 1$ & $\begin{array}{l}\text { - there are many workers and each of them separately, in comparison to } \\
\text { whole company, does really not do much, does not have a big influence } \\
\text { on employer; but if take workers as whole, they do a lot for employer }\end{array}$ \\
\hline Sheep 1/f1 & $\begin{array}{l}\text { - it likes to complain sometimes, which sound sometimes like sheep's } \\
\text { „meeee”, but it is disciplined, does not escape and keeps in pack }\end{array}$ \\
\hline
\end{tabular}

12 See: W. Kopaliński, Stownik symboli, Warszawa 2012, s. 191-194, 305-306, 452-456.

${ }^{13}$ In Polish: „,zy się stoi, czy się leży...” 
Table 2 (cont.). Zoomorphic metaphors of employee

\begin{tabular}{|c|c|}
\hline $\begin{array}{c}\text { Zoomorphic } \\
\text { metaphor/number } \\
\text { of respondents/female } \\
\text { respondents/male } \\
\text { respondents }\end{array}$ & Explanation of metaphor \\
\hline Ant 9/f8/m1 & $\begin{array}{l}\text { - must work hard, single person is not crucial for company, however the } \\
\text { whole group of workers is necessary for functioning of organization } \\
\text { - usually single one does not have a huge significance for company's de- } \\
\text { velopment, but group working means a lot; employee should be hard- } \\
\text { working, usually performs a physical work, has relatively narrow range } \\
\text { of realized tasks; he is ascribed to the concrete company's department } \\
\text { - works most and in the hardest way and his effects are seen by the "naked } \\
\text { eye" } \\
\text { - it is small and does not matter singularly but it can perform a lot in group } \\
\text { - because he works all the time and is tiny in company } \\
\text { - should be hard-working; there are many of them and in order to achieve } \\
\text { success they have to cooperate together; separately they do not have } \\
\text { much significance but together they constitute a force that has to be } \\
\text { taken into account } \\
\text { - works hard, does his best } \\
\text { - it is hard-working and small but also useful; employee should be useful } \\
\text { and work in group as ants } \\
\text { - he is hard-working, he is small in a big company, often trampled }\end{array}$ \\
\hline Ants $1 / \mathrm{f} 1$ & - hard-working; they fear nothing \\
\hline Bees 1/f1 & - all their life are occupied by honey production \\
\hline Bee $2 / \mathrm{f} 1 / \mathrm{m} 1$ & $\begin{array}{l}\text { - works hard, has little to say, usually is underestimated by his superior } \\
\text { (by the bee queen) and is treated instrumentally } \\
\text { - is able to work at the highest speed; will do everything in order to bottom } \\
\text { his tasks up }\end{array}$ \\
\hline Mouse 2/f2 & $\begin{array}{l}\text { - employee, especially of lower level, is treated in a „mass” way, equally } \\
\text { to others; means little for the whole of the company, is ,gray as mouse”; } \\
\text { must often work hard in order to achieve some gains } \\
\text { - tries not to stick out, often is afraid of disclosing his lack of contentment }\end{array}$ \\
\hline $\begin{array}{l}\text { Grey mouse under } \\
\text { broom 1/f1 }\end{array}$ & $\begin{array}{l}\text { - although that there are combative workers contributing their own ideas, } \\
\text { most of workers simply fear of lion, does not want to expose themselves } \\
\text { nor get in his way }\end{array}$ \\
\hline $\begin{array}{l}\text { Ant in ant-hill or little } \\
\text { bee in beehive } 1 / \mathrm{f}\end{array}$ & - producing honey \\
\hline Ant, bee $1 / f 1$ & $\begin{array}{l}\text { - tries to perform its tasks precisely in order to achieve good results and } \\
\text { sometimes get employer's acknowledgement }\end{array}$ \\
\hline Meerkat 1/f1 & - he's efficient, has eyes around his head, reacts fast, is alert \\
\hline Cat $1 / \mathrm{f} 1$ & $\begin{array}{l}\text { - because cats are very wise animals, which possess big cleverness, acu- } \\
\text { men, intelligence; they are able to manage in different places and situa- } \\
\text { tions }\end{array}$ \\
\hline
\end{tabular}


Table 2 (cont.). Zoomorphic metaphors of employee

\begin{tabular}{|l|l|}
\hline $\begin{array}{c}\text { Zoomorphic } \\
\text { metaphor/number } \\
\text { of respondents/female } \\
\text { respondents/male } \\
\text { respondents }\end{array}$ & \multicolumn{1}{|c|}{ Explanation of metaphor } \\
\hline Deer 1/f1 & $\begin{array}{c}\text { - skittish creature, exposed to being shot (being fired); does not have the } \\
\text { stable position }\end{array}$ \\
\hline Hen 1/f1 & $\begin{array}{c}\text { - if the employee will be cared about, he will bring more profits to com- } \\
\text { pany; his purpose is to do something for his company; so the hen is use- } \\
\text { ful to fulfil such goal as it is a source of many precious ,products" }\end{array}$ \\
\hline Moose 1/f1 & $\begin{array}{c}\text { - it should be submissive towards employer, static, can speak his opinion, } \\
\text { but in a static manner }\end{array}$ \\
\hline Giraffe 1/f1 & $\begin{array}{c}\text { - gentle animal (or at least for me it associates to be as such); long neck } \\
\text { associates for me with ambitious employee who wants to develop who } \\
\text { climbs up to the steps of his career }\end{array}$ \\
\hline Fox /f1 & - cunning; can often do everything in order to earn or does nothing \\
\hline
\end{tabular}

Source: own elaboration.

The narration related to justification of choice of employee metaphors ought to be treated in a multidimensional manner, as in the case of employer's metaphors. There are behavioral elements (eg. "[...] because he works all the time [...]", "[...] performs hard work [...]") and attributive ones (eg."' ...] gentle animal [..]", “[...] slow and lazy [...]"), with predominance of narration related to behavior and action. It shows that according to respondents employees are treated instrumentally and not with individual manner. Tthey are associated mainly with performing tasks and exhibiting impulses. Rarely concrete features are ascribed to them. Also the narration concerning relations is noticed. (" [...] submissive towards employer, [...] can speak his opinion, but in a static manner [...]", "[...] most of workers simply fear of lion [...]").

In analyzed narration the predominant idea is employee's vulnerability to being hurt and being exposed to repressions of employer (eg. "skittish creature, exposed to being shot (being fired); does not have the stable position"). Also the helplessness and lack of possibility to influence on his own situation by the worker can be noticed (,,it likes to complain sometimes, which sound sometimes like sheep's 'meeee', but it is disciplined, does not escape and keeps in pack"). The lack of significance of one separate employee for the company is emphasized but also the statements of the higher significance of groups and teams of workers is underlined $(,[\ldots]$ there are many of them and in order to achieve success they have to cooperate together; separately they do not have such significance but together they constitute a force that has to be taken into account") The necessity of hard work, which is often necessary for survival, is underlined (,,[...]must often work hard in order to achieve some gains [...]). In spite of that, there are exceptions such as vision of dishonest and cunning worker who try to keep his work effort to minimum (,,[...]can often do everything in order to earn or does nothing"). Nevertheless, most popular view of employee is being the weakest part of employer-employee relation, underestimated and being at the mercy of employer (,, [...] often trampled", "has to perform the commands [...])without courage or possibility 
to oppose the employer, ("[...] it should be submissive towards employer, static, can speak his opinion, but in a static manner") and having only an instrumental meaning (,,[...]his purpose is to do something for his company; so the hen is useful to fulfil such goal as it is a source of many precious 'products'“).

It also should be noticed that the symbolic meaning of chosen animals associates with being loyal (dog) and hard-working (bee). Some manners of understanding of employeremployee relations are even evident by reading information added to the species of animals (like trained doggy or gray mouse under broom).

\section{CONCLUDING REMARKS}

The research presented in the paper can be concluded by focusing on three matters: a) merit outcomes (concerning the employer - employ relation and characteristic of those positions), b) comments on result in the context of research group (explanation of how the choice of respondents could possibly influence the results) c) methodical comments and limitations (concerning the assessment of appropriateness of the chosen method).

Concluding the results of research it should be stressed that although in the description of employers and employees the three aspects: attributional, behavioral and relational were distinguished, finally all of them constitute the meaning given to the employer-employee relation. The main aspects of characteristics of those two roles are summarized in table 3 .

Table 3. Identification of employer and employee characteristic emerging from research

\begin{tabular}{|l|l|}
\hline \multicolumn{1}{|c|}{ Employer } & \multicolumn{1}{|c|}{ Employee } \\
\hline- cunning and clever & - prone to be hurt \\
- commanding respect or even fear & - hard-working \\
- majestic & - non-respected and underestimated \\
- dangerous & - instrumentally treated \\
- skilled to win over its competitors & - non-assertive towards employer \\
- controlling entire business & - separately unimportant, significant in group \\
& - opportunistic and lazy \\
\hline
\end{tabular}

Source: own elaboration.

The employer is characterized mostly by his features, mainly dignity, force and selfassurance. In opposite, employee is described mainly by his contribution related to the job and his attitude towards employer, manly respect and fear and sometimes also attempts of tricking him. As can be seen, the relation between employer and employee is perceived then mostly in the power-subordinance context. The relation is understood as unsymmetrical, especially in the context of mutual influence. The impact of employer on employees is perceived to be strong in many spheres. The influence of one single employee on employer and his business is reckoned to be rather insignificant.

The outcomes of the research are strongly related to the choice of respondents. It should be stressed that interpretation of employer-employee relations is under the influence of characteristic of respondent group, which is quite homogenous, particularly the special education (study) profile, possible specific future employer profile, similar possible career choice, age and career perspectives. 
Particularly it should be noticed that research was conducted among young people being at the start of their professional career. Consequently they take position of employees. They do not feel confidant on the labor market and in their firs jobs. Therefore they perceive the employer-employee relation as strongly hierarchical, even oppressive. Moreover, most of the respondent students started or will start career as an ordinary worker in finance $\&$ accounting centers or accounting bureaus. Therefore they will do only a small piece of accountant's work. Consequently, they have opinion that one separate worker is not important and has a little contribution to company's result whereas the whole team influence the success of company. The reason of such perception should be ascribed to the fact that people who are employed in finance \&accounting centers or accounting bureaus usually are responsible only for a small "piece" of accounting like recording similar operations or keeping one tyoe of accounts or specializing only in separate division of accounting, like tax accounting. Consequently, in order to achieve a "final result" of accounting, such as financial statement, the effects of actions of many ordinary accountants are needed.

Method focused on narration proved to be relevant. In the research material, apart from metaphors with explicit connotations (such as lion associated with power and pride, bee associated with hard work or fox associated with being cunning and clever) also the more unclear metaphors were used. Some of them could be interpreted in very different manners (like cat or dog) or hardly ever encountered (such as hippo) or some which associated for respondents with very peculiar way (like moose).

The presented results can be compared to comparable research conducted by A. Postuła and A. Pawłowska ${ }^{14}$. They used projection techniques with animal metaphors in order to study the perception of employer-employee relationship and investigated other groups of respondents such as: management students of fifth (last) year of unitary master studies, management students of first year of bachelor studies, entrepreneurs-employers, unemployed people aged $45+$. Their findings relating to both groups of students were similar as the results presented in this paper. Their respondents perceive the employer-employee relation as unsymmetrical and point out mostly the negative "face" of employers. Postuła and Pawłowska ${ }^{15}$ attribute it to the managerial education. As the accounting students interpretation of employer-employee relation is similar, the opinion of those researchers should be corrected. According to the author of this paper, the much more importance should be given to young age and the position of the respondents as newcomers to labor market. Also, the results should be attributed to general negative social perception of employers. It was identified by B. Glinka whose research showed that in Poland there are negative connotations of entrepreneurs and entrepreneurship and that although many positive examples of good Polish employers exists, still the media and society put much more attention towards the negative ones ${ }^{16}$.

It should be taken into account, that the sense of some metaphors explanations, especially when idiomatic, could be unclear as result of translation or the meaning can be

\footnotetext{
${ }^{14}$ A. Postuła, A. Pawłowska, Pracownik i pracodawca: wykorzystanie technik projekcyjnych $w$ badaniu postrzegania wzajemnych relacji, „Problemy Zarządzania” 2014, 12/1; A. Postuła, A. Pawłowska, Pracownik i pracodawca w perspektywie studentów zarządzania - wyzwania dla edukacji menedżerskiej, „Studia i Materiały” 2/2016 (22), cz. 2, Wydział Zarządzania Uniwersytetu Warszawskiego.

15 Ibidem.

${ }^{16}$ B. Glinka, Kulturowe uwarunkowania przedsiębiorczości w Polsce, Warszawa 2008.
} 
changed a little beat. The study of effects of translation of metaphors was discussed by J. Ostanina-Olszewska and K. Despot ${ }^{17}$. Nevertheless, it was analyzed from the context of literature translation basing on „Brothers Karamazov” case, which cases much more problems with interpretation tan just narrations of students on animal metaphors.

\section{RREFERENCES}

1. Baldwin M., Landau M.J., Swanson T.J., Metaphors can give life meaning, Self and Identity, August 2017, p. 1-31.

2. Glinka B., Kulturowe uwarunkowania przedsiębiorczości w Polsce, PWE, Warszawa 2008.

3. Hancock B., Windridge K., Ockleford E., An Introduction to Qualitative Research, The NIHR RDS EM / YH, 2009.

4. Jing-Schmidt Z, Peng X., Winds and tigers: metaphor choice in China's anti-corruption discourse, "Lingua Sinica" 2017, 3:2, p. 1-26.

5. Lakoff G., Johnson M., The Metaphorical Structure of the Human Conceptual System, „Cognitive Science” 1980, No. 4, p. 195-208.

6. Kopaliński W., Stownik symboli, Oficyna Wydawnicza RYTM, Warszawa 2012.

7. Ostanina-Olszewska J., Despot K.S., When soul is lost in translation: Metaphorical conceptions of soul in Dostoyevsky's original Bratia Kramazov (The Brothers Karamazov) and its translations into Polish, Croatian and English, Cognitive Studies/Études cognitives, 2017 (17), p. 1-16.

8. Pawełczyk A., Łojek E., Pawełczyk T., Metaphor processing in schizophrenia patoens: a study of comprehension and explanation of metaphors, "Psychology of Language and Communication” 2017, Vol. 21, No. 1, p. 287-306.

9. Postuła A., Pawłowska A., Pracownik i pracodawca: wykorzystanie technik projekcyjnych w badaniu postrzegania wzajemnych relacji, „Problemy Zarządzania” 2014, 12/1, p. 30-49.

10. Postuła A., Pawłowska A., Pracownik i pracodawca w perspektywie studentów zarzadzania - wyzwania dla edukacji menedżerskiej, „Studia i Materiały” 2016, 2(22), cz. 2, Wydział Zarządzania Uniwersytetu Warszawskiego, p. 131-145.

11. Schmitt R., Systematic Metaphor Analysis as a Method of Qualitative Research, "The Qualitative Report" 2005, Vol. 10, No. 2, June, p. 358-394.

12. Woodside A.G., Using the Forced Metaphor-Elicitation Technique (FMET) to Meet Animal Companions within Self, "Journal of Business Research" 2008, No. 61.

\section{JAK STUDENCI RACHUNKOWOŚCI POSTRZEGAJĄ RELACJE PRACODAWCA - PRACOWNIK? BADANIA JAKOŚCIOWE Z UŻYCIEM METAFORY ZOOMORFICZNEJ}

Relacja pomiędzy pracodawcą a pracownikiem jest tematem zainteresowań wielu grup, w tym studentów będących w momencie wejścia na rynek pracy i dokonywania wyboru swojej kariery zawodowej. Celem niniejszego artykułu jest identyfikacja i eksploracja postrzegania

\footnotetext{
17 J. Ostanina-Olszewska, K.S. Despot, When soul is lost in translation: Metaphorical conceptions of soul in Dostoyevsky's original Bratia Kramazov (The Brothers Karamazov) and its translations into Polish, Croatian and English, "Cognitive Studies/Études cognitives" 2017 (17), p. 1-16.
} 
przez studentów rachunkowości ról pracownika i pracodawcy oraz relacji między nimi. Postawiono następujące pytania badawcze: 1) W jaki sposób studenci rachunkowości postrzegają rolę pracodawcy? 2) W jaki sposób studenci rachunkowości postrzegają role pracownika? 3) W jaki sposób studenci rachunkowości postrzegają relacje pomiędzy pracodawcą a pracownikiem? Rozważania przedstawione $\mathrm{w}$ artykule są dokonane $\mathrm{w}$ ramach paradygmatu interpretacyjno-symbolicznego. Przejęto indukcyjne podejście badawcze. Zastosowano badania jakościowe. Użyto techniki wymuszonej metafory. Wyniki bazowały na analizie metafor oraz uzasadniających i dobór narracji. Badanie wykazało, iż pomimo wyodrębnienia trzech sposobów opisu: atrybucyjnego, behawioralnego i relacyjnego, każdy z ich w konsekwencji prowadzi do charakterystyki relacji pomiędzy pracodawcą a pracownikiem. Pracodawca charakteryzowany jest głownie poprzez swoje cechy, takie jak dostojeństwo, siła oraz pewność siebie. Pracownik jest opisywany przede wszystkim poprzez jego wkład w pracę oraz postawę wobec pracodawcy, np., szacunek i strach oraz, czasami, próby przechytrzenia go. Relacja pomiędzy pracodawcą a pracownikiem jest postrzegana głównie w kontekście władzy i podległości. Jest ona postrzegana jako asymetryczna, w szczególności w sferze wzajemnego wpływania na siebie. Wpływ pracodawcy na pracownika postrzegany jest jako silny w wielu wymiarach. Wpływ pojedynczego pracownika na pracodawcę i jego biznes jest szacowany jako raczej nieistotny.

Słowa kluczowe: rola pracodawcy, rola pracownika, relacja pracodawca-pracownik, studenci rachunkowości, metafora zoomorficzna, techniki projekcyjne, technika wymuszonej metafory.

DOI: $10.7862 /$ rz.2018.hss.81

Tekst złożono do redakcji: czerwiec 2018 r. Tekst złożono do druku: grudzień 2018 r. 
